DOI: 10.17951/lrp.2020.39.1.75-91

\author{
Elżbieta Dolata \\ Uniwersytet Rzeszowski \\ ORCID - 0000-0003-1902-1410
}

\title{
CZASOPISMO „MUZEUM” \\ W DYSKUSJI O ZADANIACH WYCHOWAWCZYCH SZKOŁY NA PRZEŁOMIE XIX I XX WIEKU
}

\begin{abstract}
Streszczenie: Na przełomie XIX i XX wieku w Europie rozgorzała burzliwa dyskusja dotycząca koncepcji nauczania i wychowania. Pedagogika tego okresu została zdominowana przez idee naturalizmu i indywidualizmu, co w konsekwencji przyczyniło się do przemian w systemie edukacji. Szerokie grono osób zaangażowanych w sprawy oświaty dyskutowało o kształcie ówczesnej szkoły. Na ziemiach polskich niezmiernie istotnym forum wymiany poglądów na temat edukacji, kultury i oświaty stały się czasopisma pedagogiczne. Ścierały się tu przede wszystkim poglądy przedstawicieli nowego wychowania i szkoły tradycyjnej. Do toczącej się dyskusji o szkole żywo włączyło się galicyjskie czasopismo „Muzeum”. Był to miesięcznik, który ukazywał się we Lwowie w latach 1885-1939 jako organ Towarzystwa Nauczycieli Szkół Wyższych i adresowany był do osób związanych ze szkolnictwem średnim. W artykule zawarto wnioski z analizy treści artykułów dotyczących zadań wychowawczych szkoły, ukazujących się w całym okresie wydawania „Muzeum”. Tocząca się na łamach czasopisma dyskusja koncentrowała się wokół kilku obszarów tematycznych. Najczęściej poruszano kwestie związane z modelem organizacyjnym szkół, omawiano nowatorskie koncepcje wychowania oraz dyskutowano o roli nauczyciela w procesie nauczania i wychowania. Przeprowadzona analiza pozwala stwierdzić, że autorzy tekstów publikowanych na łamach „Muzeum” włączyli się z dużym zaangażowaniem w dyskusję o szkole. Można uznać również, że „Muzeum” występowało jako reprezentant nowatorskich koncepcji wychowania. Inspirowało do podejmowania unowocześniania procesu nauczania i wychowania, z odwołaniem się do wzorów zagranicznych. Odegrało ogromną rolę w popularyzacji i adaptacji do polskich warunków zachodnioeuropejskiej myśli pedagogicznej. Zapoznawało polskich nauczycieli z jej dorobkiem i kierunkami rozwoju, przyczyniając się do lepszego zrozumienia roli wychowania w rozwoju społeczeństw.
\end{abstract}

Słowa kluczowe: historia wychowania, nowe wychowanie, zadania szkoły na przełomie XIX i XX wieku 


\section{WPROWADZENIE I CEL PRACY}

Pedagogika przełomu XIX i XX wieku została zdominowana przez idee naturalizmu i indywidualizmu. Odwołując się do poglądów Jana Jakuba Rousseau i Jana Henryka Pestalozziego oraz najnowszych badań psychologicznych nad dzieckiem, pedagodzy ogłosili wiek XX „stuleciem dziecka”. Równocześnie podjęli działania zmierzające do zreformowania tradycyjnej szkoły. Opracowane nowatorskie systemy pedagogiczne, m.in. przez Johna Deweya, Helenę Parkhurst, Marię Montessori, Owidiusza Decroly'ego czy Edwarda Claparede’a stały się wyznacznikiem koncepcji zmiany szkoły w USA i Europie Zachodniej.

Adaptacji haseł nowego wychowania do warunków szkolnych podjęli się również polscy pedagodzy. Rozgorzała wśród nich burzliwa dyskusja dotycząca koncepcji nauczania i wychowania. Niezmiernie istotnym forum wymiany poglądów stały się czasopisma pedagogiczne. Na ich łamach zaczęto szeroko omawiać sprawy edukacji, kultury i oświaty. Ścierały się tu przede wszystkim poglądy przedstawicieli nowego wychowania i szkoły tradycyjnej. Do toczącej się dyskusji nad koncepcją szkoły żywo włączyły się również czasopisma galicyjskie, a wśród nich szczególne miejsce zajęło „Muzeum”.

Celem artykułu jest prześledzenie toczącej się na łamach czasopisma „Muzeum" dyskusji o zadaniach wychowawczych szkoły na przełomie XIX i XX wieku oraz naszkicowanie prezentowanego w piśmie modelu wychowawczego szkoły, z uwzględnieniem jego ponadczasowych elementów. W związku z tym poddano analizie treść artykułów dotyczących koncepcji szkoły i jej potrzeb, które były publikowane przez cały okres wydawania czasopisma, tj. w latach 1885-1939. Tematyka ta gościła często na łamach pisma i była prezentowana w formie dłuższych artykułów, ale też bieżących informacji, sprawozdań czy recenzji.

Analiza treści artykułów pozwala stwierdzić, że dyskusja o zadaniach wychowawczych szkoły koncentrowała się wokół kilku obszarów tematycznych. Najczęściej wypowiadano się na temat:

- modelu organizacyjnego szkoły,

- koncepcji wychowania w „nowej szkole”,

- zadań nauczyciela w procesie dydaktyczno-wychowawczym.

Temat podjęty $\mathrm{w}$ artykule uznano za istotny $\mathrm{z}$ uwagi na to, że spór o kształt szkoły ma charakter ponadczasowy, a wiele kwestii podejmowanych w miesięczniku pozostaje nadal aktualnych. 


\section{OPIS STANU WIEDZY}

Funkcjonowanie czasopisma „Muzeum” oraz jego zawartość były już przedmiotem zainteresowania historyków wychowania. Wydane publikacje dotyczą zarówno działalności Towarzystwa Nauczycieli Szkół Wyższych - wydawcy czasopisma, jak i samego periodyku oraz poruszanej w nim problematyki. Zagadnieniom tym poświęcili teksty m.in. Teresa Gumuła, Barbara Łuczyńska, Janina Chodakowska ${ }^{1}$. Badacze akcentują znaczenie TNSW i jego organu wydawniczego „Muzeum” dla kreowania koncepcji szkoły i budowania systemu szkolnictwa średniego na ziemiach polskich na przełomie XIX i XX wieku.

„Muzeum” ukazywało się we Lwowie w latach 1885-1939, było miesięcznikiem adresowanym do osób związanych ze szkolnictwem średnim. Jako organ TNSW czasopismo rejestrowało czynności Zarządu i kół Towarzystwa, ale było również informatorem i propagatorem nowej pedagogiki, prezentowało sprawozdania i recenzje wybitnych dzieł pedagogicznych, oceniało podręczniki szkolne oraz dbało o interesy zawodowe nauczycieli szkół średnich². Czasopismo cieszyło się międzynarodowym autorytetem, skupiało najwybitniejszych teoretyków i praktyków wychowania, zarówno okresu galicyjskiego, jak i Polski międzywojennej. $\mathrm{Z}$ redakcją pisma współpracowało blisko 900 osób $^{3}$. O twórcach pisma wydano w 2013 roku artykuł pt. O zasłużonych redaktorach czasopisma „Muzeum” (18851939) ${ }^{4}$. Została w nim ukazana historia „Muzeum” przez pryzmat biografii jego redaktorów. Przez 54 lata ukazywania się pisma do grona jego redaktorów należeli: Roman Palmstein, Maurycy Maciszewski, Bolesław Ferdynand Mańkowski, Jerzy Dunin-Wąsowicz, Jan Szarota, Juliusz Wojciech Saloni, Marian Janelli, Ludwik Jaxa-Bykowski, Piotr Zygmunt Dąbrowski, Władysław Olszewski, Kazimierz Brończyk ${ }^{5}$. W prezentacji redaktorów autorka podkreśliła ich wpływ na profil i pełnione przez czasopismo funkcje $e^{6}$.

${ }^{1}$ T. Gumuła, 1990, Z dziejów „Muzeum” 1885-1939. W setna rocznicę założenia czasopisma. W: S. Walasek (red.), Z historii szkolnictwa i myśli pedagogicznej w Polsce 1779-1939. Wrocław, s. 169-179; T. Gumuła, 1989, Czasopismo „Muzeum” - organ Towarzystwa Nauczycieli Szkót Wyższych. W: A. Meissner (red.), Z dziejów oświaty w Galicij. Rzeszów, s. 139-150; B. Łuczyńska, 1984, TNSW wobec problemów nauczycieli szkót średnich (1884-1918), Kraków; J. Chodakowska, 1984, Udział TNSW w walce o polska szkołę średniq w Galicji, Rozprawy z Dziejów Oświaty i Wychowania, t. XXVI. Wrocław.

2 T. Gumuła, $Z$ dziejów „Muzeum”..., dz. cyt, s. 169.

3 Wykaz współpracowników „Muzeum”, 1909, „Muzeum”, aneks, s. XV.

4 W. Szulakiewicz, 2013, O zasłużonych redaktorach czasopisma „Muzeum” (1885-1939). W: I. Michalska, G. Michalski (red.), Addenda do dziejów oświaty; z badań nad prasa XIX i początków XX wieku. Łódź, s. 105-117.

${ }^{5}$ Tamże.

6 Tamże, s. 115. 
Okres wydawania pisma jest ściśle związany z rozwojem nowatorskich nurtów pedagogicznych. W kilku publikacjach podkreślono znaczenie „Muzeum” w popularyzacji koncepcji nowego wychowania na ziemiach polskich, a przede wszystkim w Galicji. Kwestie te podejmuje m.in. Kazimierz Szmyd, Teresa Gumuła, Elżbieta Dolata?.

Wśród istniejących opracowań brakuje szczegółowego odniesienia się do zadań wychowawczych szkoły. W związku z tym skoncentrowano się na tej tematyce i podjęto próbę odczytania na nowo koncepcji wychowawczej szkoły, ze szczególnym zwróceniem uwagi na te jej elementy, które mają znaczenie również współcześnie.

\section{MODEL ORGANIZACYJNY SZKOŁY}

W omówieniu postulowanego modelu organizacyjnego szkoły przełomu XIX i XX wieku autorzy testów zamieszczanych na łamach „Muzeum” odnosili się najczęściej do wzorów zachodnich. Przykładowo w 1908 roku Józef Lewicki omówił bardzo szczegółowo funkcjonowanie szkół w różnych krajach europejskich: w Anglii, Francji, Szwajcarii, Niemczech i Szwecji ${ }^{8}$. Akcentował, że nadrzędnym celem wychowawczym w każdej z prezentowanych szkół „nowego typu” jest swobodny i harmonijny rozwój sił dziecka. W prezentowanych szkołach była też istotna troska o zdrowie i obyczaje. Autor chwalił system organizacyjny omawianych placówek i zachęcał do czerpania z nich przykładu przy organizowaniu szkół polskich. Według poczynionych rozważań podstawą modelu organizacyjnego, wzorem szkół zachodnich, powinny być:

1. Odpowiednie położenie budynku szkolnego (w cichej okolicy i w otoczeniu przyrody).

${ }^{7}$ K. Szmyd, 2000, Zachodnia myśl pedagogiczna i jej postulaty reform szkoły średniej na łamach kwartalnika „Muzeum” (1890-1914). W: A. Meissner, C. Majorek (red.), Pedagogika nowego wychowania w Polsce u schyłku XIX i w pierwszej połowie XX wieku, seria Galicja i jej dziedzictwo, t. 14. Rzeszów, s. 193-204; T. Gumuła, 2010, Gimnazja w pierwszych dziesięcioleciach XX wieku w świetle zawartości czasopisma „Muzeum”. W: I. Michalska, G. Michalski (red.), Czasopiśmiennictwo okresu drugiej Rzeczypospolitej jak źródło do historii edukacji. Łódź, s. 21-31; T. Gumuła, 1999, Recepcja pedagogiki nowego wychowania na ziemiach polskich (na podstawie czasopisma „Muzeum”). „Acta Scientifica Academiae Ostroviensis", z. 5, s. 153-174; E. Dolata, 2012, Znaczenie wychowania estetycznego w kształtowaniu tożsamości kulturowej młodzieży galicyjskiej w świetle czasopisma „Muzeum”. W: K. Szmyd, E. Barnaś-Barnat, E. Dolata, A .Śniegulska (red.), Myśl i praktyka edukacyjna w obliczu zmian cywilizacyjnych, t. 1. Rzeszów, s. 443-459.

${ }^{8}$ J. Lewicki, 1908, Geneza i organizacja szkół nowego typu. „Muzeum”, t. 1, s. 306-323, $455-472$; t. 2 , s. $21-37$. 
2. Wychowanie fizyczne, uwzględniające m.in. ogrodnictwo, gry ruchowe, np. hokej, tenis, pływanie, football, modelowanie w glinie, szermierkę, introligatorstwo, drukowanie pisemek szkolnych.

3. Wychowanie artystyczne, poprzez naukę rysunków, muzykę, fotografię, literaturę, robótki z igłą, życie towarzyskie.

4. Wychowanie intelektualne, uwzględniające naukę języków, nauk matematyczno-przyrodniczych oraz historii i geografii kraju rodzinnego.

5. Wychowanie obyczajowo-religijne, poprzez pieleggnowanie tradycji, obrzędów i zwyczajów, obchodzenie świąt narodowych i uroczystości państwowych ${ }^{9}$.

Autor podkreślał dodatkowo, że w szkołach europejskich zwraca się szczególną uwagę na prace ręczne, które „wyrabiają stateczność, zgrabność, ześrodkowanie umysłu i woli, nałóg dokładności w praktycznym działaniu, rozwijają siły samooceny i wiary w siebie, dostarczając praktycznego przygotowania do pracy w przyszłym życiu, w jakiejkolwiek sferze, na jakimkolwiek stanowisku"10. Lewicki proponował, by w polskich szkołach uwzględniać wszystkie wymienione elementy organizacyjne. Zwrócił ponadto uwagę na wyposażenie szkół europejskich w sprzęty szkolne (ławki, tablice), dostosowane do potrzeb rozwojowych uczniów oraz ich dobre warunki higieniczne. W swoich tekstach zamieścił szereg fotografii dokumentujących na przykład zajęcia praktyczne, gimnastyczne, artystyczne, podkreślając równocześnie ich dużą użyteczność. Ogólne wnioski Lewickiego sprowadzały się do stwierdzenia, że „wychowanie w nowych szkołach odbywa się w środowisku naturalnym $z$ uwzględnieniem rozwoju fizycznego i moralnego dziecka; łączy w sposób wzorowy pacę fizyczną i umysłową"11. Autor apelował o zapewnienie takich sprzyjających warunków w polskich szkołach, jako koniecznych do zapewnienia prawidłowego rozwoju dzieci ${ }^{12}$.

O nowych szkołach, na łamach pisma, pisał również Mirosław Janik. W 1908 roku zamieścił on między innymi interesujące sprawozdanie ze światowej wystawy szkolnej w Paryżu. Podczas wystawy, w tzw. „pawilonie wychowania”, prezentowano makiety budynków szkolnych, przykładowe urządzenie i wyposażenie szkół, plany nauczania itp. Mirosław Janik chwalił amerykański systemem koedukacyjny, zachwycał się nowoczesnymi metodami pracy szkoły (laboratoria przedmiotowe, badania i ćwiczenia praktyczne, wykorzystywanie na przedmiotach humanistycznych tekstów źródłowych); wspaniałą organizacją wychowania fizycznego (sale gimnastyczne, boiska sportowe, różnorodne gry sportowe); podziwiał prowadzenie

\footnotetext{
9 Tamże, t. 1, s. 323.

10 Tamże, s. 458.

11 Tamże, s. 314.

12 Tamże, t. 2, s. 21-37.
} 
kółek literackich, plastycznych, muzycznych; podkreślał też nowoczesne wyposażenie szkół ${ }^{13}$. Z kolei Emil Dunikowski podkreślał walory systemu wychowawczego w szkołach amerykańskich. Pisał: „do kar należy nagana, karcer szkolny lub wykluczenie ze szkoły - kar cielesnych nie ma już prawie nigdzie w Stanach Zjednoczonych"14.

Dodatkowo, w każdym roku, w czasopiśmie publikowano sprawozdania z prac TNSW, które zawierały różne projekty reorganizacji szkół czy unowocześnienia metodyki zgodnie ze światowymi dążeniami w tej dziedzinie oraz przykłady rozwiązań już zastosowanych w polskich szkołach ${ }^{15}$. Było to doskonałe źródło wiadomości możliwych do bezpośredniego zastosowania w praktyce szkolnej.

Szczegółowa prezentacja szkół europejskich na łamach „Muzeum” dostarczała istotnych informacji, koniecznych do reformowania i unowocześniania rodzimego szkolnictwa. Treść przeanalizowanych artykułów pozwala na stwierdzenie, że czasopismo inspirowało do realizacji nowatorskich rozwiązań organizacyjnych w szkołach, z których większość jest nadal aktualna.

\section{KONCEPCJA WYCHOWANIA W „NOWEJ SZKOLE”}

Przed „nową szkołą” stawiano swoiste zadania wychowawcze. W związku z tym na łamach pisma domagano się zreformowania w polskich szkołach programów nauczania, unowocześnienia ich treści, dostosowania procesu dydaktyczno-wychowawczego do wymogów aktualnej wiedzy pedagogiczno-psychologicznej i warunków, w jakich powinna działać szkoła. Autorzy tekstów zamieszczanych na łamach pisma wielokrotnie apelowali o stosowanie w placówkach, na wzór europejskich, „nowych” rozwiązań wychowawczych. Podkreślali, że wszystkie szkoły powinny uwzględniać rozwój fizyczny, umysłowy i moralny dzieci i młodzieży oraz stwarzać warunki do pracy samokształceniowej. W związku z tym uczeń powinien być przygotowywany przede wszystkim do samodzielnego zdobywania wiedzy, która będzie użyteczna i zgodna $\mathrm{z}$ jego potrzebami ${ }^{16}$. W jednym z artykułów czytamy: „z dwóch czynności składa się zadanie szkoły: z nauczania i wychowania, obie jednakże w tak ścisłej są łączności, że trudno było wytknąć im stałe granice i jakby odrębne dziedziny. Ściślej rzecz biorąc nauczanie jest tylko jednym z środków wychowawczych, a celem właściwej całej działalności szkoły jest wychowanie, tj. ukształcenie silnej, rozumnej i etycznej woli wychowanków czyli

\footnotetext{
${ }_{13}$ M. Janik, 1908, Sprawozdanie $z$ wystawy szkolnej w Paryżu. „Muzeum”, t. 2, s. 77-98.

${ }^{14}$ E. Dunikowski, 1893, O szkole w Stanach Zjednoczonych. „Muzeum”, s. 274.

15 Polskie Muzeum Szkolne 1903-1913, 1913, „Muzeum”, s. 11.

16 Szkoła nowego typu, 1911, „Muzeum”, s. 468.
} 
ukształcenie charakteru. Cele te może szkoła osiągnąć nauczaniem, pobudzaniem i powstrzymywaniem"17.

Czasopismo „Muzeum” było propagatorem stymulowania harmonijnego rozwoju dziecka, co ma szczególne znaczenie również we współczesnej koncepcji wychowania. W piśmie znajdujemy teksty, których autorzy apelują o objęcie oddziaływaniem wychowawczym równocześnie wszystkich sfer rozwojowych dzieci. Na łamach pisma znajdujemy więc szereg artykułów o wychowaniu fizycznym, moralnym, estetycznym, moralnym i intelektualnym.

Na przykład Antoni Karbowiak, poruszając kwestie wychowania fizycznego, odwołuje się do postulatów nowego wychowania, a także koncepcji Komisji Edukacji Narodowej. Podkreśla, że wychowanie fizyczne już KEN uważała za podstawowy i konieczny czynnik edukacji. Pielęgnowanie zdrowia, rozwój sił i zręczności fizycznej uważano za obowiązek patriotyczny, a zaniedbywanie edukacji fizycznej traktowano wręcz za występek przeciw ojczyźnie ${ }^{18}$. Miedzy innymi z tego powodu inny autor w artykule z 1912 roku wysuwa żądanie, by każda szkoła zadbała o odpowiednie wychowanie fizyczne młodzieży. Apeluje o prowadzenie „całokształtu ćwiczeń fizycznych w duchu potrzeb narodowych i wymogów zdrowotnych, ze szczególnym uwzględnieniem stosunku praktycznych ćwiczeń ruchowych na wolnym powietrzu" ${ }^{\prime 1}$. W wielu artykułach podkreślano również znaczenie gimnastyki w wychowaniu dziewcząt. Za główne cele gimnastyki dla dziewcząt uznawano pobudzanie wszechstronnego rozwoju, uzyskanie prawidłowej postawy ciała oraz kształtowanie kobiecego wdzięku ${ }^{20}$. W zakresie rozwoju fizycznego za niezmiernie istotne uznawano również wychowanie higieniczne. Namawiano do zapoznawania młodzieży z zasadami racjonalnego odżywiania, dbania o czystość i spędzania czasu na świeżym powietrzu ${ }^{21}$. W jednym $z$ artykułów Odo Bujwid pisał: „należy uświadamiać młodzież w kwestii zdrowia, zaprowadzić obowiązkową higienę, a także wykładać ją nauczycielom aby znali sposoby unikania i niszczenia zarazków"22. Zwracano uwagę na konieczność wprowadzenia obowiązkowej nauki higieny szkolnej oraz zatrudnienia lekarzy szkolnych ${ }^{23}$. W toku dyskusji prezento-

${ }^{17}$ Kilka słów o wychowawczym zadaniu szkoły, 1885, „Muzeum”, s. 553.

18 A. Karbowiak, 1901, Wychowanie fizyczne Komisji Edukacji Narodowej w świetle historii pedagogii. Zadanie i doniosłość wychowania fizycznego w rozumieniu Komisyi. „Muzeum”, t. 1, s. $530-531$.

${ }^{19}$ K. Panek, 1912, Wychowanie fizyczne w programie zadań Sokolstwa Polskiego. „Muzeum”, t. 2, s. 441 .

${ }^{20}$ W sprawie wychowania cielesnego dziewcząt, 1906, „Muzeum”, t. 2, s. 288-289.

${ }^{21}$ A. Winogrodzki, 1905, Z higieny szkolnej. „Muzeum”, s. 371.

${ }^{22}$ O. Bujwid, 1903, O zapobieganiu chorobom zakaźnym w szkole i potrzebie wykładów higieny. „Muzeum”, s. 73.

${ }^{23}$ J.D., 1908, Nauka o zdrowiu w szkole. „Muzeum”, t. 2, s. 522. 
wanej na łamach „Muzeum” żądano, by przynajmniej dwa razy w tygodniu organizować dzieciom zajęcia ruchowe na powietrzu; latem zabawy i gry gimnastyczne, a zimą ślizganie na lodzie lub marsze. Na łamach pisma wielokrotnie powtarzał się postulat, by wprowadzić obowiązkową naukę gimnastyki ${ }^{24}$. Z czasopismem współpracował wybitny polski higienista i popularyzator gimnastyki Eugeniusz Piasecki, który wielokrotnie podejmował tematykę zdrowotną. Jego postulaty, popierane przez szerokie grono lekarzy i higienistów, dotyczyły głównie: zapewnienia w szkołach odpowiednich warunków higieniczno-zdrowotnych, zakładania sal gimnastycznych, boisk szkolnych, terenów do zabaw i gier oraz zatrudniania w szkołach lekarzy szkolnych ${ }^{25}$.

Doceniając wychowawcze wartości ćwiczeń fizycznych, na łamach pisma domagano się przeprowadzenia reformy wychowania fizycznego, zwiększenia ilości godzin ćwiczeń fizycznych w szkołach, przygotowywania nauczycieli do prowadzenia gimnastyki, organizowania gimnastyki dla dziewcząt. Pisali o tym m.in. Roman Palmstein, Eugeniusz Piasecki, Edmund Cenar, Henryk Jordan ${ }^{26}$. Dzięki Henrykowi Jordanowi - krzewicielowi kultury fizycznej w Galicji - nowym składnikiem wychowania fizycznego w szkołach średnich stały się warsztaty pracy fizycznej (np. stolarstwo, introligatorstwo). Zajmowano się też wychowaniem higieniczno-zdrowotnym, wycieczkami dla młodzieży szkolnej, koloniami zdrowotnymi i wakacyjnymi.

Za równie ważną kwestię uznawano wychowanie intelektualne młodzieży. Podkreślano, że organizacja szkoły powinna być taka, by nauczanie i wychowanie nie pozostawały w sprzeczności z potrzebami rozwojowymi młodzieży. Na przykład Henryk Grosman podkreślał, że szkoła powinna uczyć tego, czego współczesne życie ludzkie wymaga, co powiększa i pogłębia zrozumienie wartości tego życia. Musi przede wszystkim kształcić u uczniów zdolności do samokształcenia i samodzielnego rozwoju ${ }^{27}$. Z jednej strony apelowano o wyposażanie młodzieży w gruntowną wiedzę szkolną, $\mathrm{z}$ drugiej zaś przestrzegano przed nadmiernym obciążeniem wygórowanymi wymaganiami oraz pracami domowymi ${ }^{28}$. Podkreślano,

${ }^{24}$ M. Warmiński, 1897, W sprawie gimnastyki. „Muzeum”, s. 788.

${ }^{25}$ E. Piasecki, 1902, Reforma wychowania fizycznego. „Muzeum”, s. 8-12; Postulaty wychowania fizycznego młodzieży szkolnej, 1912, „Muzeum”, t. 1, s. 143-144; Kongresy międzynarodowe wychowania fizycznego, 1912, „Muzeum”, t. 2, s. 520.

${ }^{26}$ E. Piasecki, E. Cenar, 1903, Plany szczegółowe do nauki gimnastyki. „Muzeum”, s. 453-454; R. Palmstein, 1892, W sprawie fizycznego wychowania młodzieży. „Muzeum”; S. Ciechanowski, 1913, Kilka uwag o koloniach wakacyjnych. „Muzeum”, t. 1, s. 23-33.

${ }_{27}$ H. Grosman, 1912, Kongres niemiecki dla poznania kształcenia młodzieży. „Muzeum”, t. 2, s. $502-514$.

${ }^{28}$ K. Krotowski, 1895, O przeciążeniu naszej młodzieży w szkołach średnich. „Muzeum”, s. 123. 
że należy przede wszystkim „krzepić w umysłach młodzieży poczucie obowiązku, wolną wolę, energię i wytrwałość”29 .

Autorzy tekstów wielokrotnie podkreślali również znaczenie wychowania estetycznego. Wśród najcenniejszych jego form wymieniano m.in. wystawy, koncerty, przedstawienia dla młodzieży, zapoznawanie z literaturą i sztuką, naukę śpiewu i rysunku ${ }^{30}$. Zadanie wychowawcze szkoły w tym zakresie to wpajanie ukochania przyrody, uczenie poszanowania dzieł sztuki i kształcenie smaku estetycznego ${ }^{31}$. Podkreślano, że pełny rozwój osobowości ucznia jest możliwy poprzez uwrażliwienie go na piękno przyrodniczego i kulturalnego otoczenia. Dlatego szkoła powinna zadbać nie tylko o wykształcenie naukowe, ale także o rozwój „moralno-estetyczny”. Na przykład I.L. Tadd proponował zwrócenie uwagi na przeżycia związane z przyrodą, budzenie do niej aktywnego stosunku, pielęgnowanie żywego związku uczuciowego i praktycznej wiedzy o niej ${ }^{32}$. Pisano: „W duszy dziecka tkwi głęboko wkorzenione poczucie piękna, które powinno być rozwijane i kształcone drogą należytego wychowania"33. Sugerowano, by w wychowaniu estetycznym uwzględniać naukę muzyki i rysunku ${ }^{34}$. Oddziaływanie estetyczne powinno też dotyczyć budynku szkolnego, jego wyglądu, otoczenia oraz urządzenia sal lekcyjnych ${ }^{35}$.

$\mathrm{Na}$ łamach pisma toczyła się również wymiana myśli na temat wychowania moralnego i światopoglądowego. Szczegółowe rozważania z tego zakresu podjął Wilhelm Borner. W tekście opublikowanym w 1909 roku sformułował on pytania brzmiące bardzo współcześnie. Pytał na przykład: czy wprowadzać do szkoły systematyczną naukę moralności, czy jedynie nauczać religii? Czy nauczać etyki obok religii, czy zastąpić naukę religii nauczaniem etyki i moralności? W swoich rozważaniach zauważył, że w wychowaniu moralnym ważny jest przede wszystkim nauczyciel, który własnym przykładem powinien oddziaływać na rozwój moralny uczniów $^{36}$. Z kolei Madeleine Derbon twierdziła, że celem wychowania moralnego jest „rozwijanie, przy pomocy lektury, opowiadań i rozmówek metodycznych uczuć sprzyjających rozwojowi moralnemu i zrozumienia celu bytu jednostki

${ }^{29}$ R.S.K. Okólnik w sprawie obniżania się poziomu naukowego i właściwego wymiaru pracy domowej, 1913, „Muzeum”, t. 2, s. 298-301.

${ }^{30}$ Wychowanie estetyczne, 1907, „Muzeum”, t. 2, s. 77-78, 91, 372.

${ }^{31}$ E. Fiszer, 1910, Wychowanie estetyczne. „Muzeum”, t. 1, s. 527-528.

32 I.L. Tadd, 1903, Neue Wege zur Künstlerischen Erziehung der Jugend. „Muzeum”, s. 442.

${ }^{33}$ Sztuka a dziecko, 1910, „Muzeum”, t. 1, s. 94.

${ }^{34}$ J. Kleiner, 1913, W sprawie należytego wyzyskania dzieł sztuki i zabytków historycznych dla celów szkolnych. „Muzeum”, t. 2, s. 486-493; L. Jaworski, 1907, Muzyka w gimnazjach i szkołach realnych. „Muzeum”, s. 165-167; L. Jaworski, 1907, Doniosłość nauki rysunków. „Muzeum”, s. 325-328.

${ }^{35}$ S. Pszon, 1913, Jak wyrabiać poczucie piękna w szkole. „Muzeum”, t. 2, s. 145.

${ }^{36}$ W. Borner, 1909, Zadanie I metoda wychowania moralnego. „Muzeum”, t. 2, s. 597. 
w społeczeństwie ${ }^{37}$. Z kształtowaniem charakteru wiązano również moralność seksualną. Podkreślano konieczność podejmowania z nastolatkami (powyżej 16. roku życia), tematów dotyczących czystości płciowej i zachowania moralnego. Przestrzegano więc przed korzystaniem $z$ „niemoralnych” książek i obrazów. Przypominano, że „wraz z upadkiem moralności giną narody, a człowiek, który w jednej dziedzinie życia zachowuje się niemoralnie, nie może być moralnym w innej" ${ }^{38}$. W tekście pt. Znaczenie refleksji ucznia dla pracy kształcącej szkót autor podkreślił, że zadaniem wychowawczym szkoły jest wychowanie jednostki, która będzie mogła kiedyś samodzielnie pracować umysłowo i współistnieć moralnie. Szkoła nie może ograniczyć się do podawania wiedzy, ale ma przede wszystkim uczyć metod i sposobów wszechstronnego (umysłowego, fizycznego i duchowego) rozwijania swojej osoby. Cel ten szkoła może osiągnąć, jeżeli pobudzi ucznia do zastanowienia się nad sobą, obserwowania i poznawania siebie ${ }^{39}$. W końcu podkreślano, że szkoła powinna „podnieść moralno-religijny poziom młodzieży; uszlachetnić jej uczucia patriotyczne; wpłynąć na podniesienie układu towarzyskiego i uczuć estetycznych"40.

Sporo miejsca w piśmie zajmowała kwestia kształcenia dziewcząt. Zwracano uwagę na konieczność dostosowania treści kształcenia do potrzeb wynikających z przyszłych obowiązków. W jednym $\mathrm{z}$ artykułów autor przekonuje, że celem wychowania dziewcząt powinno być „przygotowanie do przyszłej działalności w rodzinie jako żony i matki i w społeczności jako świadomej obywatelki”"1. W związku z tym wzorem szkół francuskich autor postuluje wprowadzenie do edukacji dziewcząt m.in. psychologię dziecka, nauki o zdrowiu i żywieniu, rachunkowość, zagadnienia socjalne, język ojczysty, literaturę ojczystą, wiadomości $\mathrm{z}$ zakresu historii i kultury własnego narodu ${ }^{42}$.

Można uznać, że „Muzeum”, zgodnie z wielokrotnie przytaczanymi słowami Friedricha Foerystera, postulowało, by „kształcenie zmierzało do głównego celu wychowania, jakim jest harmonijne wytworzenie człowieka w człowieku, u którego

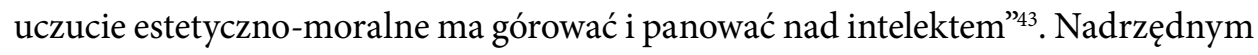
celem wychowania ma być przygotowanie do życia w społeczeństwie. Równocześnie zgodnie z nowym nurtem wychowanie powinno być oparte na aktywności dziecka,

37 M. Darbon, 1909, Nauka moralności w liceach i kolegiach akademii. „Muzeum”, t. 2, s. 454.

38 A.G., 1910, Moralność seksualna w szkole. „Muzeum”, t. 1, s. 188.

${ }^{39}$ H. Gauding, 1911, Znaczenie refleksji ucznia dla pracy kształcącej szkót. „Muzeum”, s. 59.

${ }^{40}$ B. Bandrowski, 1912, Zepsucie dzisiejszej młodzieży gimnazjalnej i środki zaradcze. „Muzeum", t. 2, s. 89.

${ }^{41}$ J.D., 1908, Nowoczesne wychowanie dziewczat. „Muzeum”, t. 2, s. 164.

42 Tamże.

${ }^{43}$ M. Bienenstock, 1908, Wychowanie etyczne w świetle teorii Fr. W. Foerystera. „Muzeum”, t. 1 , s. $43-58,191-197,352-360$. 
a efektem pracy wychowawczej ma być człowiek uspołeczniony, wolny i aktywny. Teoretycy podkreślali znaczenie swobody w wychowaniu. Postulowali ponadto, by pracę wychowawczą szkoły wiązać ze środowiskiem społecznym, korzystać z tego środowiska i równocześnie na nie oddziaływać.

\section{ZADANIA NAUCZYCIELA \\ W PROCESIE DYDAKTYCZNO-WYCHOWAWCZYM}

Czasopismo „Muzeum” wykazywało wyjątkowe zainteresowanie sprawami nauczycieli i starało się dbać o interesy zawodowe tej grupy społecznej. Świadczą o tym chociażby zamieszczane na łamach pisma sprawozdania z posiedzeń TNSW oraz innych towarzystw i kół nauczycielskich. Wynika z nich, że kwestie nauczycielskie były bardzo często przedmiotem obrad. Dyskutowano zarówno o przygotowaniu nauczycieli do pracy, modelu organizacyjnym placówek kształcących nauczycieli, jak i zastanawiano się nad sposobami poprawy ich sytuacji materialnej ${ }^{44}$. Z zamieszczanych sprawozdań wynika również, że systematycznie dzielono się spostrzeżeniami dotyczącymi stosowanych przez nauczycieli metod i form pracy pedagogicznej oraz omawiano ich zaangażowanie w działalność społeczno-oświatową ${ }^{45}$.

W piśmie zamieszczono szereg artykułów z informacjami o przedsięwzięciach krajów zachodnich, zmierzających do stworzenia jak najlepszego systemu kształcenia nauczycieli. Na przykład Edyta Bartoniówna w roku 1908 roku szczegółowo opisała system wychowawczy seminariów nauczycielskich w Anglii. Istniały tam dwa odrębne typy seminariów, przygotowujące do pracy w szkołach elementarnych oraz średnich. Placówki kształcące nauczycielki były prywatne. Wszystkie posiadały szeroką autonomię, zatrudnieni w nich nauczyciele decydowali samodzielnie o doborze metod pracy, podręcznikach, programach nauczania do poszczególnych przedmiotów. Dużą część zajęć stanowiły samodzielne prace uczniów oraz zajęcia praktyczne. W programie nauczania seminariów znajdowały się: psychologia, historia naturalna, fizyka, chemia, fizjologia, higiena, rysunki, prace ręczne, nauka wymowy, gimnastyka, gry. Istotne miejsce w programie nauczania stanowiły tzw. lekcje próbne, czyli praktyka w szkołach. Dzięki nim nauczycielki zdobywały praktyczne przygotowanie do zawodu. W seminariach zakładano kółka literackie,

${ }^{44}$ XX Walne Zgromadzenie Towarzystwa Pedagogicznego, 1886, „Muzeum”, s. 468-470.

${ }^{45}$ Szerzej na ten temat: D. Grabowska-Pieńkosz, 2017, Działalność nauczycieli w towarzystwach społeczno-oświatowych w latach 1885-1918 w świetle sprawozdań na łamach „Muzeum”. W: P. Gołdyn (red.), Działalność Związków i organizacji nauczycielskich w XIX i pierwszej połowie XX wieku. Poznań, s. 23-37. 
przyrodnicze, artystyczne, sprzyjające rozwijaniu zainteresowań i samokształceniu uczennic ${ }^{46}$. Autorka przekonywała, by korzystać ze wspaniałych angielskich doświadczeń, ale równocześnie w pracy wychowawczej zwracać uwagę na to, co narodowe, ojczyste i bliskie.

W piśmie wielokrotnie zwracano uwagę na słabe strony polskiego systemu przygotowania nauczycieli do pracy. Postulowano, wzorem placówek zachodnich, wprowadzenie dla nauczycieli praktycznego kształcenia poprzez odbywanie praktyk w szkołach i prowadzenie obserwacji lekcji ${ }^{47}$. Za niezmiernie istotne uznawano również poszerzenie w programach kształcenia nauczycieli wiadomości z zakresu psychologii dziecka ${ }^{48}$. Na temat pedagogicznego i dydaktycznego przygotowania nauczycieli do pracy wypowiadał się kilkukrotnie Jerzy Harwot. Proponował, by nauczycieli wyposażać w gruntowną wiedzę pedagogiczną poprzez wprowadzenie obowiązkowych wykładów z pedagogiki podczas studiów oraz dodatkowe ćwiczenia praktyczne ${ }^{49}$.

W kilku tekstach zamieszczonych w piśmie znajdujemy cenne, praktyczne wskazówki do pracy wychowawczej dla nauczycieli. W artykule z 1893 roku czytamy: „Wprawiać trzeba dziecię w nałóg dobrych spraw - przestrzegając, aby się do niczego złego nie przyzwyczaiło. Bo nasienie złego jest trudne do wytępienia, a łatwe do rozkrzewienia i gdy je wyrywać będziesz, podobno złamiesz prędzej, niż poprawisz" ${ }^{\prime 50}$. Metodą wychowawczą powinien być dobry przykład i autorytet nauczyciela. W jednym z tekstów czytamy: „miłością więcej można sprawić niż niewolniczą bojaźnią i przymusem. Najlepiej jest, jeżeli uczeń nauczyciela swego kocha i wstydzi się go, w drugim rzędzie najlepszą rzeczą jest, jeżeli się go boi; źle jest, jeżeli go nienawidzi; najgorzej, jeżeli nim gardzi" ${ }^{51}$. Jeden $\mathrm{z}$ autorów przekonuje wręcz, że najmniej skuteczny jest przymus. Za szkodliwe uznaje takie zachowanie, gdzie nauczyciel „rzuca się jak opętany: jednego w pysk, drugiego w łeb, trzeciego kolankiem poniżej bioder, uczniów nazywa szubrawcami, z nich jeden leży chory, drugi z rozbitą o tablicę głową, trzeci z oberwanymi uszami" ${ }^{2}$. Autor tekstu zaleca umiar i łagodne traktowanie podopiecznych.

W wielu tekstach wskazywano również na konieczne do pracy pedagogicznej predyspozycje osobowościowe nauczycieli. Wymieniano przede wszystkim poczucie misji, odpowiedzialność, moralność, kreatywność. Na przykład Edyta Bartoniów-

46 E. Bartoniówna, 1908, Seminaria nauczycielskie w Anglii. „Muzeum”, t. 2, s. 77-99.

47 Konferencja dyrektorów szkół średnich galicyjskich, 1893, „Muzeum”, s. 314-328.

48 R. Dybowski, 1939, Postulaty neofilologiczne. „Muzeum”, s. 96-105.

49 J. Harwot, 1886, W sprawie pragmatyki służbowej. „Muzeum”, s. 323-329.

50 Tamże.

51 Tamże.

${ }^{52}$ O godności i moralnym prowadzeniu stanu nauczycielskiego w naszej szkole średniej, 1904, „Muzeum”, s. 579. 
na stwierdzała: „W dzisiejszych czasach postępu ogólnego nauczyciele potrzebują szerszego, praktycznego doświadczenia, połączonego z gruntownymi wiadomościami teoretycznymi, gdyż takie zespolenie i uzupełnienie obu tych stron uczyni dopiero nauczyciela człowiekiem, który potrafi wejść należycie w swe powołanie"53.

Analiza treści artykułów z tego zakresu pozwala stwierdzić, że „Muzeum” było zwolennikiem nowych, aktualnych do dziś koncepcji wychowawczych, skłaniających nauczycieli do twórczej, zindywidualizowanej pracy wykorzystującej znajomość psychiki dziecka. Ponadto było rzecznikiem interesów stanowych nauczycieli, pragnęło dla nich szacunku i troszczyło się o ich byt.

\section{PODSUMOWANIE}

Przeprowadzona analiza zawartości „Muzeum” pozwala stwierdzić, że autorzy tekstów publikowanych na jego łamach, włączyli się z dużym zaangażowaniem do dyskusji o wychowaniu. Analiza treści zamieszczanych tekstów potwierdza, że „Muzeum” występowało jako reprezentant nowatorskich koncepcji wychowania, których wiele aspektów ma charakter ponadczasowy i jest aktualnych również dzisiaj. Można zauważyć, że w trakcie działalności pismo coraz bardziej otwierało się na nowe idee i zmiany, publikując coraz więcej tekstów prezentujących zachodnioeuropejską myśl pedagogiczną. Stopniowo stawało się więc znaczącym popularyzatorem nowego wychowania na ziemiach polskich. Zapoznawało polskich nauczycieli z dorobkiem pedagogiki i kierunkami jej rozwoju, przyczyniając się do lepszego zrozumienia roli wychowania w rozwoju społeczeństw. Inspirowało do podejmowania działań unowocześniających proces nauczania i wychowania, z odwołaniem się do wzorów zagranicznych. Założenia programowe i wychowawcze, o których dyskutowano na łamach pisma, weszły do dorobku polskiej praktyki pedagogicznej, m.in. wychowanie moralne, obywatelskie, zdrowotne, fizyczne, i są realizowane w szkołach do dziś. Upowszechniło się też wyposażanie nauczycieli w wiedzę psychologiczno-pedagogiczną, konieczną w pracy dydaktyczno-wychowawczej.

Na podkreślenie zasługuje fakt, że myśli formowane na przełomie XIX i XX wieku mogą jeszcze dziś stanowić inspirację dla współczesnych idei wychowawczych, opartych na kształceniu pojęciowym, odwołującym się do samoedukacji ucznia, jego motywacji i zdolności do uczenia się dla własnego samorozwoju. Dylematy edukacyjne tamtego czasu, ale też aktualne dzisiaj, oddaje cytat: „Każda jednostka stawia życiu wielkie i wyrafinowane wymagania, a wszędzie spotkać można

\footnotetext{
${ }^{53}$ E. Bartoniówna, dz. cyt., s. 93.
} 
pewną tęsknotę, pewne dziwne, nieokreślone uczucia. Wszystko rwie się naprzód w nowszym pospiechu, wszędzie dąży do skracania przestrzeni, czasu, nakładu trudu i pracy. Żyje się szybko, nikt nie ma czasu nawet do skupienia myśli, wejścia w siebie, zastanowienia się nad sobą i stąd pochodzi uczucie pustki, nudy, niesmaku" ${ }^{4}$. Można stwierdzić więc, że zagadnienia i postulaty pedagogiczne dotyczące zadań wychowawczych szkoły podejmowane na łamach „Muzeum” przed niemal stu laty mają charakter uniwersalny i aktualny do dziś.

\section{LITERATURA}

A.G., 1910, Moralność seksualna w szkole. „Muzeum”, t. 1.

Bandrowski B., 1912, Zepsucie dzisiejszej młodzieży gimnazjalnej i środki zaradcze. „Muzeum”, t. 2.

Bartoniówna E., 1908, Seminaria nauczycielskie w Anglii. „Muzeum”, t. 2.

Bienenstock M., 1908, Wychowanie etyczne wświetle teorii Fr. W. Foerystera. „Muzeum”, t. 1.

Borner W., 1909, Zadanie I metoda wychowania moralnego. „Muzeum”, t. 2.

Bujwid O., 1903, O zapobieganiu chorobom zakaźnym w szkole i potrzebie wykładów higieny. „Muzeum”.

Chodakowska J., 1984, Udział TNSW w walce o polską szkołę średnią w Galicji, Rozprawy z Dziejów Oświaty i Wychowania, t. XXVI. Wrocław.

Ciechanowski S., 1913, Kilka uwag o koloniach wakacyjnych. „Muzeum”, t. 1.

Darbon M., 1909, Nauka moralności w liceach i kolegiach akademii. „Muzeum”, t. 2. Dolata E., 2012, Znaczenie wychowania estetycznego w kształtowaniu tożsamości kulturowej młodzieży galicyjskiej w świetle czasopisma „Muzeum”. W: K. Szmyd, E. Barnaś-Barnat, E. Dolata, A. Śniegulska (red.), Myśl i praktyka edukacyjna w obliczu zmian cywilizacyjnych, t.1. Rzeszów.

Dunikowski E., 1893, O szkole w Stanach Zjednoczonych. „Muzeum”.

Dybowsk R., 1939, Postulaty neofilologiczne. „Muzeum”.

Fiszer E., 1910, Wychowanie estetyczne. „Muzeum”, t. 1.

Gauding H., 1911, Znaczenie refleksji ucznia dla pracy kształcącej szkół. „Muzeum”. Gloss M., 1907, Über Künsterziehung. „Muzeum”.

Grabowska-Pieńkosz D., 2017, Działalność nauczycieli w towarzystwach społecznooświatowych w latach 1885-1918 w świetle sprawozdań na łamach „Muzeum”. W: P. Gołdyn (red.), Działalność Związków i organizacji nauczycielskich w XIX i pierwszej połowie XX wieku. Poznań.

${ }^{54}$ M. Gloss, Über Künsterziehung. „Muzeum”1907, s. 676. 
Grosman H., 1912, Kongres niemiecki dla poznania kształcenia młodzieży. „Muzeum”, t. 2 .

Gumuła T., 1989, Czasopismo „Muzeum”- organ Towarzystwa Nauczycieli Szkót Wyższych. W: A. Meissner (red.), Z dziejów oświaty w Galicji. Rzeszów.

Gumuła T., 2010, Gimnazja w pierwszych dziesięcioleciach XX wieku w świetle zawartości czasopisma „Muzeum”. W: I. Michalska, G. Michalski (red.), Czasopiśmiennictwo okresu drugiej Rzeczypospolitej jak źródło do historii edukacji. Łódź.

Gumuła T., 1999, Recepcja pedagogiki nowego wychowania na ziemiach polskich (na podstawie czasopisma „Muzeum”). „Acta Scientifica Academiae Ostroviensis”. Gumuła T., Z dziejów „Muzeum” 1885-1939. W setna rocznicę założenia czasopisma. W: S. Walasek (red.), Z historii szkolnictwa i myśli pedagogicznej w Polsce 1779-1939. Wrocław 1990.

Harwot J., 1886, W sprawie pragmatyki służbowej. „Muzeum”.

J.D., 1908, Nauka o zdrowiu w szkole. „Muzeum”, t. 2.

J.D., 1908, Nowoczesne wychowanie dziewcząt. „Muzeum”, t. 2.

Janik M., 1908, Sprawozdanie z wystawy szkolnej w Paryżu. „Muzeum”, t. 2.

Jaworski L., 1907, Muzyka w gimnazjach i szkołach realnych. „Muzeum”.

Jaworski L., 1907, Doniosłość nauki rysunków. „Muzeum”.

Karbowiak A., 1901, Wychowanie fizyczne Komisji Edukacji Narodowej w świetle historii pedagogii. Zadanie i doniosłość wychowania fizycznego w rozumieniu Komisyi. „Muzeum”.

Kilka słów o wychowawczym zadaniu szkoły, 1885, „Muzeum”.

Kleiner J., 1913, W sprawie należytego wyzyskania dzieł sztuki i zabytków historycznych dla celów szkolnych. „Muzeum”, t. 2.

Konferencja dyrektorów szkół średnich galicyjskich, 1893, „Muzeum”.

Krotowski K., 1895, O przeciążeniu naszej młodzieży w szkołach średnich. „Muzeum”.

Lewicki J., 1908, Geneza i organizacja szkół nowego typu. „Muzeum”, t. 1, t. 2.

Łuczyńska B., 1984, TNSW wobec problemów nauczycieli szkół średnich (1884-1918). Kraków.

O godności i moralnym prowadzeniu stanu nauczycielskiego w naszej szkole średniej, 1904, „Muzeum”.

Palmstein R., 1892, W sprawie fizycznego wychowania młodzieży. „Muzeum”.

Panek K., 1912, Wychowanie fizyczne w programie zadań Sokolstwa Polskiego. „Muzeum", t. 2.

Piasecki E., Cenar E., 1903, Plany szczegółowe do nauki gimnastyki. „Muzeum”.

Piasecki E., 1912, Kongresy międzynarodowe wychowania fizycznego. „Muzeum”, t. 2.

Piasecki E., 1902, Reforma wychowania fizycznego. „Muzeum”, t. 1.

Polskie Muzeum Szkolne 1903-1913, 1913, „Muzeum”.

Postulaty wychowania fizycznego młodzieży szkolnej, 1912, „Muzeum”, t. 1. 
Pszon S., 1913, Jak wyrabiać poczucie piękna w szkole, „Muzeum”, t. 2.

R.S.K. Okólnik w sprawie obniżania się poziomu naukowego i właściwego wymiaru pracy domowej, 1913, „Muzeum”.

Szkoła nowego typu, 1911, „Muzeum”.

Szmyd K., 2000, Zachodnia myśl pedagogiczna i jej postulaty reform szkoly średniej na łamach kwartalnika „Muzeum” (1890-1914). W: A. Meissner, C. Majorek (red.), Pedagogika nowego wychowania w Polsce u schytku XIX iw pierwszej połowie $X X$ wieku, seria Galicja i jej dziedzictwo, t. 14. Rzeszów.

Sztuka a dziecko, 1910, „Muzeum”, t. 1.

Szulakiewicz W., 2013, O zastużonych redaktorach czasopisma „Muzeum” (1885-1939).

W: I. Michalska, G. Michalski (red.), Addenda do dziejów oświaty; z badań nad prasa XIX i początków XX wieku. Łódź.

Tadd I.L., 1903, Neue Wege zur Künstlerischen Erziehung der Jugend. „Muzeum”. W sprawie wychowania cielesnego dziewczat, 1906, „Muzeum”, t. 2.

Warmiński M., 1897, W sprawie gimnastyki. „Muzeum”.

Winogrodzki A., 1905, Z higieny szkolnej. „Muzeum”.

Wychowanie estetyczne, 1907, „Muzeum”, t. 2.

Wykaz wspótpracowników „Muzeum”, 1909, „Muzeum”.

XX Walne Zgromadzenie Towarzystwa Pedagogicznego, 1886, „Muzeum”.

\title{
THE „MUSEUM” MAGAZINE IN THE DISCUSSION ON THE EDUCATIONAL TASKS OF THE SCHOOL AT THE TURN OF THE 19TH AND 20TH CENTURIES
}

\begin{abstract}
At the turn of the 19th and 20th centuries, in Europe, there was a heated discussion about the concept of teaching and upbringing. Pedagogy of this period was dominated by the ideas of naturalism and individualism, which in turn contributed to the changes in the education system. A wide range of people involved in educational issues discussed the shape of the school at that time. On Polish soil, pedagogical journals became an extremely important forum for the exchange of views on education, culture and education. This was the place where the views of the representatives of the "new education" and the traditional school clashed. The Galician magazine „Museum” joined the ongoing discussion about the school. It was a monthly magazine that was published in Lviv between 1885 and 1939 as an organ of the Society of Teachers of Higher Education and was addressed to people connected with secondary education. The article contains conclusions from the analysis of the content of articles concerning the educational tasks of the school, which appeared in the whole period of publishing the "Museum”. The discussion in the magazine focused on a few thematic areas. Most frequently, issues related to the organizational model of schools were raised, innovative concepts of education were discussed and the role of teachers in the process of teaching and education was discussed. The analysis carried out allows us to conclude that the authors of
\end{abstract}


the texts published in the "Museum” magazine have joined in the discussion about the school with great involvement. It can also be said that the „Museum” acted as a representative of innovative concepts of upbringing. It inspired to undertake modernization of the teaching and upbringing process, with reference to foreign models. It played an enormous role in the popularization and adaptation of Western European pedagogical thought to the Polish conditions. It acquainted Polish teachers with its achievements and directions of development, contributing to a better understanding of the role of education in the development of societies.

Keywords: history of upbringing, new upbringing, school tasks at the turn of the 19th and 20th centuries 